\title{
THE USE OF BIOLOGICAL INDICES FOR THE ASSESSMENT OF THE RIVER QUALITY (RUDA RIVER, POLAND)
}

\author{
WYKORZYSTANIE INDEKSÓW BIOLOGICZNYCH \\ W OCENIE JAKOŚCI WÓD RZECZNYCH (RZEKA RUDA, POLSKA)
}

\begin{abstract}
Recognition of the deteriorating conditions of rivers worldwide has called for increased efforts to improve the ecological quality of impacted river systems. This is particularly important in areas that have suffered from a significant impact of human pressure on the ecological status of water. Field studies were conducted in the Ruda River in an area that had undergone anthropogenic disturbances. The objectives of our survey were to test the biological metrics based on benthic macroinvertebrates at four study sites. Spring and autumn surveys of benthic invertebrates indicated that based on the BMWP and BMWP(PL) indices, water quality was higher in comparison with the value of Multimetric index at all of the sites that were studied. Our results revealed that the water quality was higher at the study sites that are located above the dam reservoir based on both the chemical and biological parameters. This study also indicated that both spring and autumn constitute appropriate periods for carrying out monitoring studies. The values of multimeric index indicated the same water quality (except for site 1) in both sampling periods. Anthropogenic transformations of a riverbed influence the flora and fauna and affect the ecological status of rivers.
\end{abstract}

Keywords: macroinvertebrates, MMI, BMWP, ecological status of river, anthropopressure

\section{Introduction}

Significant deterioration in the quality of river water and a dramatic decline in biological diversity currently constitute a serious threat to the hydrologic and biocenotic sustainability of freshwater ecosystems [1]. A good ecological and chemical surface water status should be achieved in the countries of the European Union by 2015 according to the European Water Framework Directive (WFD) [2]. The WFD recognises benthic communities as one of the best biological indicators of the ecological status of rivers as well as for the evaluation of the integrity of aquatic ecosystems and the diagnosis of environmental risk [1, 3, 4]. As a group, macroinvertebrates are sensitive and respond to both natural and human changes in their environment (e.g.: organic pollution, the anthropogenic perturbation, or different types of river degradation) [5, 6]. Because of their

\footnotetext{
${ }^{1}$ Department of Hydrobiology, University of Silesia, ul. Bankowa 9, 40-007 Katowice, Poland, phone +48323591411

${ }^{2}$ EKOID - Environmental Protection - Geophysics: Environmental Protection, Geology, al. W. Roździeńskiego 188, 40-236 Katowice, Poland

*Corresponding author: aneta.spyra@us.edu.pl
} 
sensitivity or tolerance to environmental changes, oxygen availability [7], food availability [8], and changes in habitat structure [9], benthic macroinvertebrates are the most frequently used organisms in ecological assessment of quality in different water environments [5, 10-12]. Changes in the water quality and physical structure of rivers have caused changes in the composition of the biotic community inhabiting the river, usually with a reduction in the taxon richness and biological diversity of the aquatic ecosystem $[13,14]$.

A variety of biological methods are currently applied in Europe to evaluate the biological assessment of water quality, most of which are modules based on studies of benthic macroinvertebrates [4, 11, 15-17]. The Water Framework Directive imposes the necessity for a comprehensive analysis of all available ecological data that characterise rivers in regards to specific structural environmental parameters. This is necessary in order to define the scope and types of responses of aquatic organisms to environmental stress. Biological indices (multi-metrics system) are widely recommended and appear to be a valuable tool in monitoring macroinvertebrate response to both reference conditions and anthropogenic disturbances in rivers throughout Europe [18-24]. This technique describes the state of an ecosystem by means of a combination of different individual metrics [25-29]. They are highly recommended to demonstrate the different aspects of water quality $[2,30$, 31] and represent the structural and functional aspects of the community as well as the pollution tolerances of benthic macroinvertebrates [32]. According to Resh et al. [33], the combination of multiple metrics may also minimise the weaknesses of individual metrics.

Lotic environments are one of the most vulnerable and most exploited ecological systems on our planet [34]. For many years rivers worldwide have experienced intense pressures that are related to human activity $[35,36]$, which have had a detrimental effect on the condition of their ecosystems. Degradation of water quality that results from an increased inflow of pollutants and nutrients from agricultural, domestic and industrial sources was the first problem to be recognised as an important cause of the declining river conditions, taxonomic richness, biological diversity and they are a serious threat to river integrity [34, 37]. A good ecological status implies that all of the biological quality elements show low levels of distortion by human activity and deviate only slightly from those normally associated with this type of surface water under undisturbed conditions [2]. Anthropogenic transformation of a river bed and different disturbances like, e.g. river channelisation, disruption of river continuity by dams and weirs and flow regulation by dams affect the flora and fauna and have an influence on the ecological status of rivers. Over the last few decades efforts have been made to detect, quantify and counteract these effects [38].

In the areas of selected significant impact of human pressure in the countries of the European Union, there is a need to protect the environments in accordance with EU directives [39]. The Silesian Upland remains under serious threats to surface water quality due to its significant industrialisation and urbanisation. Pollution in the form of inadequately purified urban waste water and industrial pollution from rural areas, agricultural and recreational activities, as well as from the fish ponds, landfills and water runoff are the largest threats [40]. Despite this, in the area that was surveyed, we can distinguish sites with undeniable natural values like the catchment area of the Ruda River. For this reason, it is important to draw attention to the status of the quality of its waters. The aims of this study were: 1) to use benthic macroinvertebrates in the assessment of the ecological status of the Ruda River based on the recommended biotic indices and 2) to 
determine the optimal period for carrying out the biological monitoring of surface waters as exemplified by the Ruda River.

\section{Material and methods}

\section{Study area}

Study was carried out in the Ruda River (Southern Poland) (Fig. 1). The Ruda River catchment area has been strongly transformed as a result of human activity, which is located next to regions that have a high natural value. Forests constitute the dominant use of the Ruda River catchment area. To the structure of agricultural area belong arable land and pastures. In 1972, the Rybnik Dam Reservoir was created to dam the Ruda River. Its primary role is to cool the turbines at the Rybnik power plant. The river bed has also been transformed in some sections of the river.

The main characteristics of the study sites in the Ruda River

\begin{tabular}{|c|c|c|c|c|}
\hline & Site 1 & Site 2 & Site 3 & Site 4 \\
\hline $\begin{array}{l}\text { Flora: macrophytes, } \\
\text { other aquatic and } \\
\text { riparian species, } \\
\text { trees }\end{array}$ & $\begin{array}{c}\text { Glyceria } \\
\text { maxima }\end{array}$ & $\begin{array}{c}\text { Glyceria maxima } \\
\text { Iris pseudoacorus } \\
\text { Lemna minor } \\
\text { Solidago canadensis } \\
\text { Robinia pseudoaccacja } \\
\text { Padus serotina }\end{array}$ & $\begin{array}{c}\text { Glyceria maxima } \\
\text { Iris pseudoacorus } \\
\text { Typha latifolia } \\
\text { Solanum dulcamara } \\
\text { Lemna minor } \\
\text { Myriophyllum spicatum } \\
\text { Potamogeton crispus } \\
\text { Chara sp. }\end{array}$ & $\begin{array}{c}\text { Glyceria maxima } \\
\text { Iris pseudoacorus } \\
\text { Solidago canadensis } \\
\text { Impatiens } \\
\text { glandulifera } \\
\text { Reynoutria japonica } \\
\text { Echinocystis lobata }\end{array}$ \\
\hline Bottom sediments & $\begin{array}{l}\text { Sand-mud, } \\
\text { in the spring - } \\
\text { mud }\end{array}$ & $\begin{array}{c}\text { mud } 75 \% \\
\text { stones } 15 \% \\
\text { sand } 10 \% \\
\text { branches and roots } \\
<5 \%\end{array}$ & $\begin{array}{c}\text { gravel-sand } 50 \% \\
\text { submerged plants } 20 \% \\
\text { emerged plants } 15 \% \\
\text { algae } 15 \%\end{array}$ & $\begin{array}{l}\text { sand-mud } 90 \% \\
\text { stones } 10 \% \\
\text { branches }<5 \%\end{array}$ \\
\hline $\begin{array}{l}\text { Samples of bottom } \\
\text { sediments } \\
\text { (20 sub-samples) }\end{array}$ & $\begin{array}{l}20 \text { samples - } \\
\text { sandy-muddy } \\
\text { sediments } \\
\text { (in spring - } 20 \\
\text { samples - mud) }\end{array}$ & $\begin{array}{c}15 \text { samples - mud } \\
3 \text { samples - stones } \\
2 \text { samples - sand }\end{array}$ & $\begin{array}{c}6 \text { samples - gravel } \\
6 \text { samples - sand } \\
4 \text { samples - submerged } \\
\text { plants } \\
2 \text { samples - emerged } \\
\text { plants } \\
2 \text { - algae }\end{array}$ & $\begin{array}{c}18 \text { samples - } \\
\text { sandy-muddy } \\
\text { sediments } \\
2 \text { samples - stones }\end{array}$ \\
\hline $\begin{array}{c}\text { Depth of samples } \\
\text { collecting }[\mathrm{m}]\end{array}$ & $0.15-0.20$ & $0.95-1.20$ & $0.35-0.60$ & $1.70-1.85$ \\
\hline Water velocity $\left[\mathrm{m} \mathrm{s}^{-1}\right]$ & $0.10-0.22$ & $0.18-0.290$ & $0.45-1.0$ & $0.31-0.4$ \\
\hline Temperature $\left[{ }^{\circ} \mathrm{C}\right]$ & $18.3-15.9$ & $15-16$ & $16-19.8$ & $14.3-16$ \\
\hline $\mathrm{pH}[-]$ & $6.5-7.0$ & $6.1-7.2$ & $6.7-7.6$ & $7.3-7.6$ \\
\hline Conductivity $\left[\mu \mathrm{S} \mathrm{cm}^{-1}\right]$ & $590-650$ & $680-710$ & $2580-4850$ & $2140-2580$ \\
\hline TDS $\left[\mathrm{mg} \mathrm{dm}^{-3}\right]$ & $290-300$ & $330-350$ & $1290-2430$ & $1070-1250$ \\
\hline $\mathrm{NO}_{3}\left[\mathrm{mg} \mathrm{dm}^{-3}\right]$ & $14.8-21.3$ & $2.70-8.86$ & $7.1-11.1$ & $6.13-12.40$ \\
\hline $\mathrm{NO}_{2}\left[\mathrm{mg} \mathrm{dm}^{-3}\right]$ & $0.5-1.0$ & $0.40-0.46$ & $0.63-1.0$ & $0.33-0.26$ \\
\hline $\mathrm{N}-\mathrm{NH}_{4}\left[\mathrm{mg} \mathrm{dm}^{-3}\right]$ & $2.29-6.49$ & $0.49-0.69$ & $0.32-0.75$ & $0.09-0.51$ \\
\hline $\mathrm{PO}_{4}^{3-}\left[\mathrm{mg} \mathrm{dm}^{-3}\right]$ & $1.19-2.74$ & $0.14-0.39$ & $0.38-1.97$ & $0.63-0.96$ \\
\hline $\mathrm{P}\left[\mathrm{mg} \mathrm{dm}^{-3}\right]$ & $0.34-0.39$ & $0.05-0.13$ & $0.45-0.64$ & $0.21-0.31$ \\
\hline $\mathrm{Fe}\left[\mathrm{mg} \mathrm{dm}^{-3}\right]$ & $0.04-0.34$ & $0.87-1.69$ & $0.41-0.59$ & $0.59-0.60$ \\
\hline $\begin{array}{c}\text { Total hardness } \\
{\left[\mathrm{mg} \mathrm{CaCO}_{3} \mathrm{dm}^{-3}\right]}\end{array}$ & $158-165$ & $138-140$ & $310-398$ & $120-178$ \\
\hline $\mathrm{Ca}\left[\mathrm{mg} \mathrm{dm}^{-3}\right]$ & $50-58$ & $45-50$ & $80-110$ & $19-65$ \\
\hline
\end{tabular}




\begin{tabular}{|c|c|c|c|c|}
\hline & Site 1 & Site 2 & Site 3 & Site 4 \\
\hline $\mathrm{Mg}\left[\mathrm{mg} \mathrm{dm}^{-3}\right]$ & $3.32-9.75$ & $3.32-6.71$ & $26.78-29.78$ & $3.81-17.63$ \\
\hline $\begin{array}{c}\text { Alcalinity } \\
{\left[\mathrm{mg} \mathrm{CaCO}_{3} \mathrm{dm}^{-3}\right]}\end{array}$ & $62.5-115$ & $65-75$ & $160-175$ & $60-225$ \\
\hline $\mathrm{Cl}\left[\mathrm{mg} \mathrm{dm}^{-3}\right]$ & $40-81$ & $60-80$ & $580-1180$ & $350-430$ \\
\hline Land use & $\begin{array}{c}\text { agricultural } 70 \% \\
\text { mixed forests } \\
5 \% \\
\text { urban area } 5 \%\end{array}$ & $\begin{array}{l}\text { artificially planted } \\
\text { forest } 80 \% \\
\text { grasslands }\end{array}$ & $\begin{array}{l}\text { grasslands } 80 \%, \\
\text { natural mixed forests }\end{array}$ & $\begin{array}{c}\text { agricultural } 70 \% \\
\text { pastures }\end{array}$ \\
\hline Source & \multicolumn{4}{|c|}{ Baranowicze near Zory } \\
\hline Catchement area $\left[\mathrm{km}^{2}\right]$ & \multicolumn{4}{|c|}{504.06} \\
\hline River length [km] & \multicolumn{4}{|c|}{51.5} \\
\hline Ecoregion & \multicolumn{4}{|c|}{9} \\
\hline $\begin{array}{c}\text { Size typology } \\
\text { (Catchement area) }\end{array}$ & \multicolumn{4}{|c|}{ medium } \\
\hline Code of stream type & \multicolumn{4}{|c|}{10} \\
\hline Elevation [m a.s.1] & \multicolumn{4}{|c|}{274.75} \\
\hline
\end{tabular}

Four sampling sites were selected in the Ruda River: site 1 - located in the source of the river, site 2 - located above the reservoir dam, site 3 - below the reservoir dam and 4 - in the river estuary (Fig. 1, Table 1).

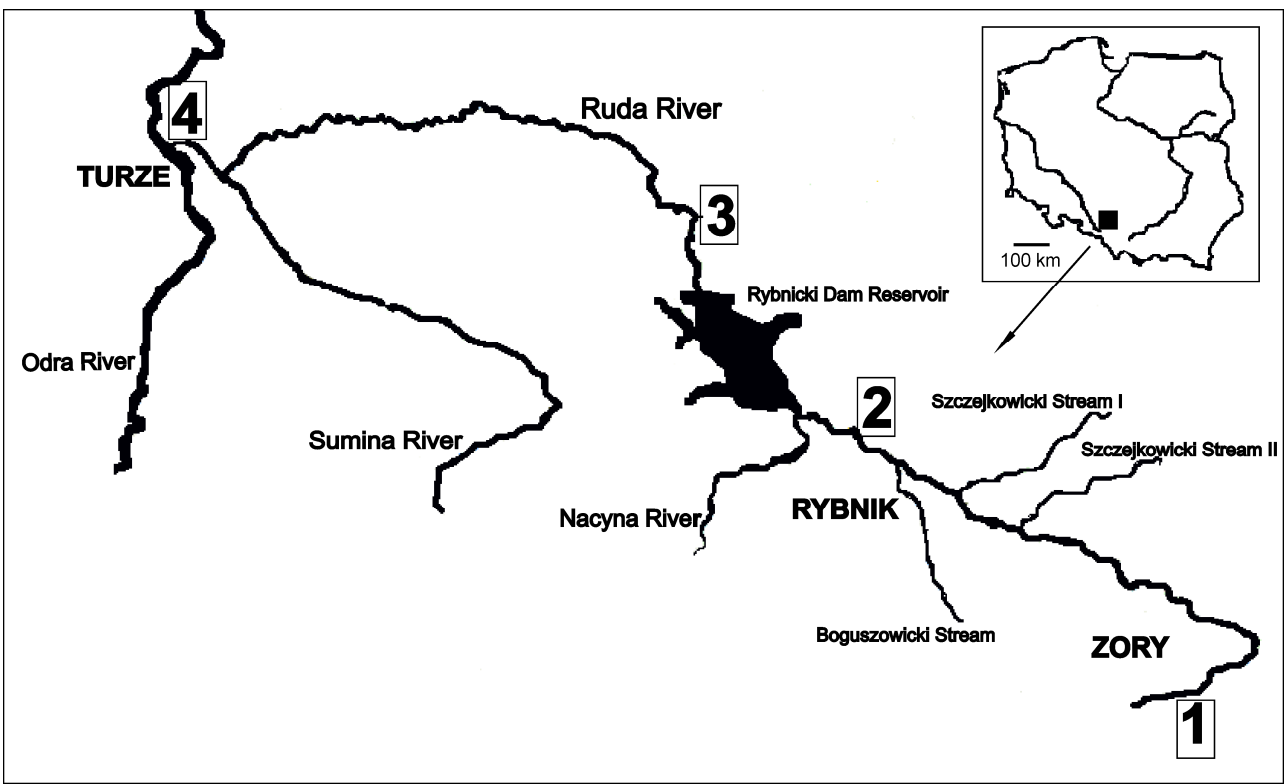

Fig. 1. Location of the study sites and the Ruda River in Poland. 1-4: sampling sites

\section{Sampling}

Selection of the sampling sites was performed in accordance with the methodology of a Multi-Habitat Sampling (MHS) with preservation of standard analytical procedures according to the requirements of the Water Framework Directive - in both the laboratory and field studies as well as in the final assessment of the ecological status [41]. The 
selection of sampling sites was related to the length of the river section and to the heterogeneity of river habitats. In medium-sized rivers with a catchment area of $100-1000 \mathrm{~km}^{2}$, samples should be taken in the transect from $50-100 \mathrm{~km}$. It was possible to move across the width of the river at the selected sites (with the exception of site 4 where the average water depth exceeded $1.70 \mathrm{~m}$ ).

Sampling to assess the ecological status of Ruda River was conducted in spring and autumn 2009 in order to confirm the optimal sampling period for biomonitoring.

The samples of benthic macroinvertebrates were collected in a $100 \mathrm{~m}$ transect at each of the sampling sites using a bottom scraper with a square frame $\left(0.18 \times 0.18 \mathrm{~m}=\right.$ a sampling surface of $\left.625 \mathrm{~cm}^{2}\right)$. Each sample consisted of 20 sub-samples (replicates, a total area of $1.25 \mathrm{~m}^{2}$ ). At the same time, the percentage of mineral and organic substrate in the bottom of river bed were estimated at each sampling site and the location of the sub-sample was selected and limited to sites that represented not less than $5 \%$ of the bottom (Table 1). During the sampling, the scraper was placed frontally to the direction of water flow. The percentage of mineral and organic substrates was estimated at $25 \mathrm{~m}$ sections in order to perform a more accurate evaluation of the various types. The sampling process took into account the correct location of samples in the gradient of typical river habitats: the bottom and the shore of the river, lotic and lentic habitats and the presence of macrophytes on various types of mineral substrates. In the laboratory, the samples were sieved with a $0.23 \mathrm{~mm}$ mesh net and then sorted under a stereoscopic microscope.

Samples of water were collected from each sampling site immediately before the sampling of macroinvertebrates. Analyses of the physical and chemical parameters of the water, e.g. temperature, conductivity and $\mathrm{pH}$ were measured in the field using a Hanna Instruments portable meter. Analyses of e.g. ammonium, nitrate, nitrite and phosphate concentrations in the water were carried out using colorimetric and titrimetric methods. According to the EU WFD size typology based on the catchment area, the Ruda River belongs to a medium river. The characteristic morphometric features of the river and its typology adopted to the Polish conditions [42] as well as the physico-chemical parameters of the water are shown in Table 1.

\section{Biotic metrics and indices}

The following indices, which are based on benthic macroinvertebrate fauna, were calculated for the assessment of the ecological status of the river Ruda [18]:

1. BMWP - Biological Monitoring Working Party index.

2. The diversity index $d$ (a modified version of the Margalef index): $d=S / \log N$, where, $S$ is the number of taxa (families), $N$ is the density of macroinvertebrates (individuals per $\left.1 \mathrm{~m}^{2}\right)$.

3. The BMWP(PL) - Biological Monitoring Working Party index adapted to the Polish conditions. The benthic macroinvertebrates were identified to the family or genus level in accordance with the requirements of the BMWP(PL) methodology.

As the components of MMI index in the assessment of the ecological status of River

Ruda we took into account the following metrics [1]:

1. The ASPT (Average Score per Taxon). The ASPT is the value of BMWP divided by the number of BMWP families that are present in the taxa list

2. The Log10 (sel EPTD+1) index (selected Ephemeroptera, Plecoptera, Trichoptera and Diptera)

3. 1-GOLD (\% of individuals from Gastropoda + Oligochaeta + Diptera) 
4. The total number of macroinvertebrate families (S)

5. The number of EPT families

6. The H' Shannon diversity index

7. ICMI (Intercalibration Common Metrics index)

8. Density of benthic macroinvertebrates - was estimated as the number of individuals per square metre

Biotic index values were calculated for benthic macroinvertebrates during spring and autumn at each study site.

The Spearman rank correlation coefficient $\left(r_{s}, p<0.05\right)$ was applied for the evaluation of the relationships between the physico-chemical variables and biotic indices. All statistical analyses were performed using the STATISTICA package (version 9).

\section{Results}

During this study, 43 benthic macroinvertebrate taxa that were represented by 41 families and two higher taxonomic ranks were recorded at the river sites studied (in total 13,888 macroinvertebrate specimens were collected). The benthic fauna was dominated by gastropods, which contributed $57 \%$ and insects - $22.5 \%$ of the total number of macroinvertebrates collection. Among the insects Hydropsychidae were the most abundant taxa (11\% of the total collection of macroinvertebrates).

Some of the macroinvertebrates that are most tolerant to water pollutions: Oligochaeta, Erpobdellidae, Asellidae, Chironomidae, Simuliidae, Sphaeriidae, Hydrobiidae and Planorbidae were found at the sampling sites. The greater degree of taxonomic richness and diversity during autumn (except for site 3) was confirmed in the values of BMWP index (Table 2). This is most likely related to the low abundance of taxa that are sensitive to pollution in the spring e.g. Limnephilidae, Polycentropodidae, Leptoceridae and Cordulegastridae.

Table 2

The values of the BMWP index, the BMWP-PL index and the Margalef's biodiversity index at the sampling sites in the Ruda River

\begin{tabular}{|c|c|c|c|c|c|}
\hline \multirow{2}{*}{ Site } & $\begin{array}{c}\text { Study } \\
\text { period }\end{array}$ & $\begin{array}{c}\text { Margalef 's } \\
\text { biodiversity index } \\
{[-]}\end{array}$ & $\begin{array}{c}\text { The value of BMWP } \\
\text { index } \\
{[-]}\end{array}$ & $\begin{array}{c}\text { The value of } \\
\text { BMWP-PL } \\
{[-]}\end{array}$ & Quality class \\
\hline \multirow{2}{*}{1} & $\mathrm{~S}$ & 2.41 & 17 & 19 & IV \\
\cline { 2 - 6 } & $\mathrm{A}$ & 6.95 & 60 & 76 & II \\
\hline \multirow{2}{*}{2} & $\mathrm{~S}$ & 6.57 & 63 & 89 & II \\
\cline { 2 - 6 } & $\mathrm{A}$ & 5.05 & 71 & 71 & II \\
\hline \multirow{2}{*}{3} & $\mathrm{~S}$ & 4.32 & 59 & 64 & III \\
\hline \multirow{2}{*}{4} & $\mathrm{~A}$ & 3.05 & 39 & 51 & III \\
\cline { 2 - 6 } & $\mathrm{S}$ & 3.79 & 41 & 60 & III \\
\hline
\end{tabular}

S - spring, A - autumn

The number of collected specimens was higher in the autumn than in the spring at each of sites that were studied and varied from 311 (site 1) to 4980 (site 4). The number of taxa varied in both study periods. In the autumn we observed a higher number of taxa than in the spring at all of the study sites except for site 3 (Fig. 2). 

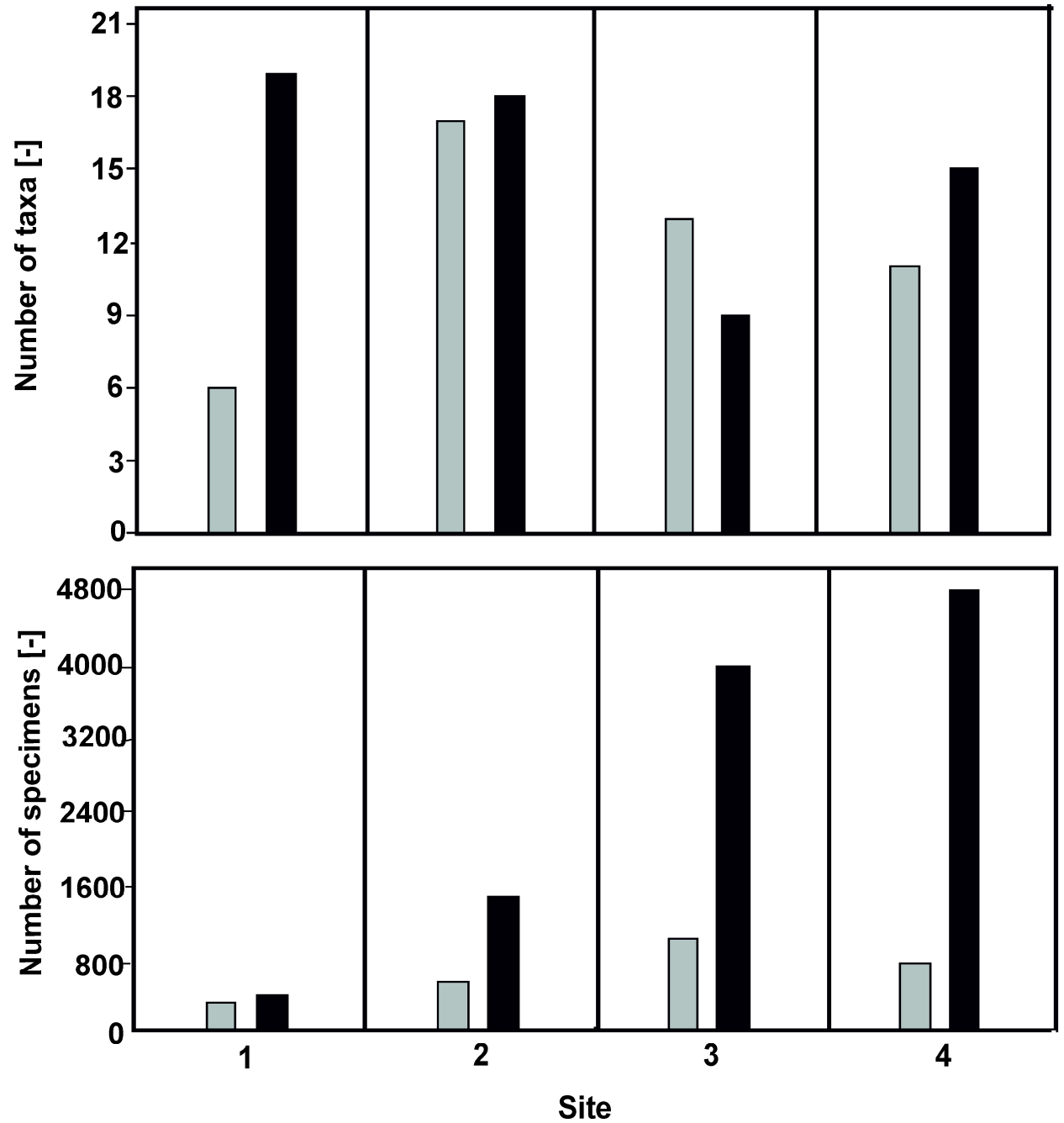

Fig. 2. Number of benthic invertebrate taxa and specimens recorded during the surveys the in Ruda River in the spring (grey columns) and autumn (black columns)

An analysis of multimeric index (MMI) in the Ruda River showed that its values indicated poor water quality at site 1 during spring (quality class $\mathrm{V}$ ). Along the course of the river the values of MMI indicated a moderate quality (site 2) (Table 3). At the study sites that are located below the Dam Reservoir (sites 3 and 4) the water was classified into the IV quality class. In autumn we observed an improvement of the water quality (site 1). The value of some indices at study site 2 indicated a good state of water quality (e.g. Shannon diversity index, Table 3), which affected the value of the MMI, which indicate a moderate state of water quality (class III) in spring. At site 3 the value of MMI allowed the water to be classified into the IV quality class. 
The values of the metrics MMI and its components that were calculated for the sites studied in the Ruda River

\begin{tabular}{|c|c|c|c|c|c|c|c|c|}
\hline & \multicolumn{2}{|c|}{ Site 1 } & \multicolumn{2}{c|}{ Site 2 } & \multicolumn{2}{c|}{ Site 3 } & \multicolumn{2}{c|}{ Site 4 } \\
\hline Metrics & S & A & S & A & S & A & S & A \\
\hline ASPT [-] & 3.17 & 4.24 & 4.94 & 4.76 & 4.92 & 4.73 & 4.55 & 4.73 \\
\hline Log10 (Sel_EPTD+1) [-] & 0.00 & 0.00 & 1.07 & 1.75 & 0.34 & 0.00 & 0.00 & 0.00 \\
\hline 1-GOLD [-] & 0.04 & 0.36 & 0.25 & 0.53 & 0.06 & 0.35 & 0.29 & 0.18 \\
\hline S [-] & 6 & 17 & 18 & 18 & 13 & 11 & 11 & 15 \\
\hline EPT [-] & 0 & 2 & 2 & 3 & 2 & 1 & 1 & 1 \\
\hline H' Shannon [-] & 0.79 & 2.08 & 1.57 & 1.92 & 0.69 & 1.07 & 1.18 & 0.64 \\
\hline ICMi [-] & 0.138 & 0.395 & 0.544 & 0.644 & 0.373 & 0.335 & 0.322 & 0.336 \\
\hline Density [ind./m²] & 373 & 470 & 655 & 1825 & 1240 & 4933 & 924 & 5976 \\
\hline MMI index [-] & 0.138 & 0.395 & 0.544 & 0.644 & 0.373 & 0.335 & 0.322 & 0.336 \\
\hline MMI - Quality class [-] & V & IV & III & III & IV & IV & IV & IV \\
\hline
\end{tabular}

$\mathrm{S}$ - spring, A - autumn

The BMWP(PL) index varied from 19 to 89 scores which, according to Polish classification, corresponded with the range of the classes IV-II of water quality, e.g. from heavily polluted to slightly polluted. A comparative analysis of the BMWP-PL and MMI indices indicated that the BMWP-PL indicated a better water quality in both periods of study in comparison with the MMI at all of the study sites. According to BMWP-PL and Margalef index, the lowest water quality (IV quality class) in the spring was found at site 1 . Along the course of the Ruda River, the values of the indices indicated a water of quality class II (site 2) and class III (sites 3 and 4). It was probably connected with the polluted tributary of the Nacyna River as well as with the pollution originating from other sources (Table 2).

The results that were obtained show that both spring and autumn represent appropriate periods to conduct monitoring studies; however, the diversity (expressed by H' Shannon index) of invertebrates in the case of sites 2 and 4 was higher in spring. It is also confirmed by the identical quality class (MMI) on sites 2, 3 and 4 in both periods of study. Changes in taxonomic richness and biodiversity have an impact on the biotic indices that are used for river quality assessment.

Site 1 was characterised by a soft water with low conductivity and a high content of nutrients. The nutrient content was lower at site 2 , especially during the autumn. At the sites that are located below the Dam Reservoir we found high values of conductivity (up to $4850 \mu \mathrm{S} / \mathrm{cm}$ ), a high content of dissolved solids, calcium, magnesium as well as a high content of chloride (up to $1180 \mathrm{mg} / \mathrm{dm}^{3}$ ). The values of total hardness that were obtained allowed it to be classified into the hard water category (Table 1).

Statistical analysis showed no significant relationship between the values of MMI, BMWP, BMWP(PL), 1-GOLD, and the physico-chemical properties of water. The number of EPT families was positively correlated with water velocity $\left(r_{s}=0.61, p<0.05\right), \log 10$ with the Fe content $\left(r_{s}=0.72, p<0.05\right)$. The Shannon' index values decreased $\left(r_{s}=-0.80\right.$, $p<0.05)$ with an increasing content of chlorides. ASPT values increased with increasing values of conductivity and total dissolved solids $\left(r_{s}=0.73\right.$ and $0.76, p<0.05$, respectively) and decreased $\left(r_{s}=-0.71, p<0.05\right)$ with an increasing content of $\mathrm{NO}_{3}$ in the water. 


\section{Discussion}

The intensity of anthropogenic activities leads to different degrees of degradation of the water environment which is, according to the WFD [2], described by one of the five ecological quality classes ranging from high to bad status. The Ruda River is exposed to human activity and the effects of human impact are visible in some of its parts in the form of, e.g., riverbed regulation and hydrotechnical facilities. The negative effects of regulation affect aquatic fauna because reduction in the diversity of river microhabitats leads to a decline in the taxonomic richness and the diversity of macroinvertebrates.

The practice of evaluating ecological river quality is very different in individual European countries [43-47]. In most cases, assessment of water quality and calculation of biotic indices includes different analysis of invertebrates e.g.: exact or relative abundance of species or higher taxa, diversity, dominance, taxonomic composition, family tolerance score and other significant biotic parameters [30, 48-51]. The BMWP scoring system and its national variants were commonly believed to provide consistent information on water quality [52] and the same applied to the Polish BMWP-PL index [38, 53, 54] which was developed in Poland in order to standardise Polish biomonitoring methods for assessing the quality of water with those that are used in the European Union [55]. In a study conducted by Wyzga et al. [56], the highly variable BMWP-PL index scores were unrelated to the physico-chemical properties of the river water, which consistently indicated a high water quality. This was confirmed in our study in which we also found no statistically significant correlations between BMWP, BMWP (PL) and the physico-chemical properties of water. Such findings confirm that the composition of macroinvertebrate communities is sensitive to hydromorphological degradation [57]. In our study, the BMWP values indicated a better water quality in comparison with the MMI, while according to the value of the BMWP-PL index and Margalef's index, the water can be classified as II (sites 1 and 2) and III class (sites 3 and 4).

The biological metrics that were analysed in our research are known to be some of the key indicators. They vary significantly with the specific type of stressor and its intensity, which means that they describe the changing environmental conditions very well [41]. These metrics provide information on three major response areas and fulfil the criteria for the Water Framework Directive: tolerance, e.g. ASPT [58]; abundance/habitat, e.g. Log 10 (Sel_EPTD +1); 1-GOLD; the total number of macroinvertebrate taxa; the number of EPT Families [59-62] and diversity, e.g. the Shannon-Wiener diversity index. A multimetric index integrates different individual measures into a single value that can potentially reflect multiple effects of human impact on the structure and function of aquatic ecosystems $[3,63]$. The most effective use of such tools occurs when there is a clear understanding of the mechanisms that lead to the presence or absence of a species in the environment [53]. The investigation of Camargo [64] and Lucke and Johnson [24] has clearly shown that the multimetric approach, which is based on benthic macroinvertebrates, may also be a useful technique for the biological assessment of nutrient enrichment in fluvial ecosystems.

An increase of nutrient content in lotic ecosystems is a more widespread phenomenon than that in lentic waters $[60,65]$. The major anthropogenic sources that cause freshwater nutrient enrichment are industrial wastes, animal farming, agricultural and urban runoff and sewage effluents. In this research we have shown a significant nutrient content in the water of the Ruda River. Reservoirs, especially large ones are generally accepted to be sinks of nutrients (and other materials) due to a reduction in water velocity and an increase in water 
depth [65]. In light of that, our research showed small differences in nutrient content at the sites that are located above and below the Dam Reservoir. The values of other physicochemical parameters were different among the sampling sites. Therefore, a significant increase of, e.g., conductivity, total dissolved solids and chloride concentrations was found at sampling sites that are located below the Rybnicki Reservoir (sites 3 and 4). This may be related to the inflow of pollutants, e.g., with the water of Nacyna River, and it seems to be the primary cause of the changes in the abundance of benthic macroinvertebrates at the sites that are located below the Rybnicki Reservoir. Conductivity can be regarded as one of the major variables that play a crucial role in explaining the gradient in the distribution of benthic macroinvertebrates in rivers [6].

It was concluded from our research that the water quality was higher at the study sites that are located above the Rybnicki reservoir based on both chemical and biological parameters. In our researches, we observed the occurrence of taxa that are characteristic for habitats with a fine-grained substrate that is overgrown with aquatic plants, e.g. Hydrobiidae and Planorbidae as well as widely tolerant taxa mainly Oligochaeta, Erpobdellidae, Asellidae and Chironomidae. The waste water treatment affected the quality of the water and caused a strong decrease in the abundance of taxa such as, e.g. Limnephilidae, Polycentropodidae, Leptoceridae and Cordulegastridae where the Ruda River passed the reservoir. This is not surprising since these aquatic invertebrates usually exhibit a high sensitivity to freshwater pollution [6, 64, 66, 67].

The recommended sample collection of macrobenthos for different types of biological monitoring should be carried out once a year in the spring [1]. The best growing season for benthic macroinvertebrates is spring or autumn and furthermore, it is recommended that macroinvertebrate sampling in rivers be carried out during spring or autumn in order to avoid the more extreme hydrological regime and temperature conditions $[31,68]$. Our research showed that the river was characterised by the greatest diversity (expressed in the Shannon diversity index) on three of the four sampling sites in the autumn, which may suggest that autumn is probably a better period for carrying out monitoring study. However, the values of multimeric index indicated the same water quality (except for site 1) in both sampling periods.

Multimetric indices are increasingly applied for the purpose of conservation actions, since they allow water resources monitoring agencies to get insight in complex biological data [25]. Therefore, they have become a popular modes for regional assessment of aquatic resources in many European countries including also Poland. The results of this study showed that the degree of water pollution has a visible influence on the occurrence of macroinvertebrates. At site 2, which was characterised by better water quality, we observed a greater degree of diversity of benthic invertebrates in comparison to the sites that are located in the further parts of the Ruda River in which the number of zoobenthos individuals was higher but the number of taxa was smaller. This relation was confirmed in the results that were obtained because in spite of the strong human pressure the Ruda River creates the habitat conditions for the occurrence of benthic invertebrate fauna. Research concerned with the use of the biological indices that are applied to benthic macroinvertebrates for river quality assessment are extremely relevant as long as the WFD requires an assessment system for all types of rivers, lakes, transitional and coastal waters based on a number of biological quality elements, including benthic macroinvertebrates to be developed. There is still a need for more intensive study and further testing of the effectiveness of the multimeric index in different freshwater environments. 


\section{Conclusions}

The research which was conducted in the Ruda River in order to test the biological metrics based on benthic macroinvertebrates allowed to formulate the following conclusions from the data analysis:

- Both spring and autumn constitute appropriate periods for conducting monitoring studies. The values of multimetric index indicated the same water quality (except for site 1) in both sampling periods.

- $\quad$ Irrespective of sampling period, it can be concluded that based on the values of BMWP and BMWP(PL) indices water quality was higher in comparison with the value of Multimetric index at sampling sites of this study.

- Anthropogenic transformations of a riverbed affect the ecological status of rivers, the water quality was higher at the study sites located above the dam reservoir based on both the chemical and biological parameters.

\section{References}

[1] Bis B, Mikulec A. Przewodnik do oceny stanu ekologicznego rzek na podstawie makrobezkręgowców bentosowych. (Guide to assessment the ecological status of rivers based on benthic macroinvertebrates). Warszawa; 2013. http://www.gios.gov.pl/images/dokumenty/pms/monitoring_wod/przewodnik_do_oceny_ stanu_ekologicznego_rzek_makrobentos_2013.pdf.

[2] EU Directive 2000/60/EC of the European Parliament and of the Council of 23 October 2000 establishing a framework for Community action in the field of water policy. OJEU, L327,1; 2000.

[3] Kenney MA, Sutton-Grier AE, Smith RF, Gresens SE. Benthic macroinvertebrates as indicators of water quality: The intersection of science and policy. Terrestrial Arthropod Reviews. 2009;2:99-128. DOI: 10.1163/187498209X12525675906077.

[4] Bis B, Zdanowicz A, Zalewski M. Effects of catchment properties on hydrochemistry, habitat complexity and invertebrate community structure in a lowland river. Hydrobiologia. 2000;422/423:369-387.

[5] Tripole S, Vallania EA, Corigliano MC. Benthic macroinvertebrate tolerance to water acidity in the Grande river sub-basin (San Luis, Argentina). Limnetica. 2008;27(1):29-38.

[6] Lewin I, Czerniawska-Kusza I, Szoszkiewicz K, Ławniczak AE, Jusik S. Biological indices applied to benthic macroinvertebrates at reference conditions of mountain streams in two ecoregions (Poland, the Slovak Republic). Hydrobiologia. 2013;709:183-200. DOI: 10.1007/s10750-013-1448-2.

[7] Saloom ME, Duncan RS. Low dissolved oxygen levels reduce anti-predator behaviors of the freshwater clam Corbicula fluminea. Freshwater Biol. 2005;50:1233-1238. DOI: 10.1111/j.1365-2427.2005.01396.x.

[8] Cross WF, Wallace JB, Rosemond AD, Eggert SL. Whole-system nutrient enrichment increases secondary productivity in a detritus-based ecosystem. Ecology. 2006;87:1556-1565. DOI: 10.1890/012-9658(2006)87[1556:WNEISP]2.0.CO;2.

[9] Steinman AD, Conklin J, Bohlen PJ, Uzarski DG. Influence of cattle grazing and pasture land use on macroinvertebrate communities in freshwater wetlands. Wetlands. 2003;23:877-889. DOI: 10.1672/0277-5212(2003)023[0877:IOCGAP]2.0.CO;2.

[10] Mykra H, Saarinen T, Tolkkinen M, Mcfarland B, Hamalainen H, Martinmaki K, et al. Spatial and temporal variability of diatom and macroinvertebrate communities: How representative are ecological classifications within a river system? Ecol Indic. 2012;18:208-217.

[11] Rosenberg DM, Resh VH. Freshwater biomonitoring and benthic macroinvertebrates. In: Freshwater Biomonitoring and Benthic Macroinvertebrates. New York: Chapman \& Hall; 1993.

[12] Almeida SFP, Feio MJ. DIATMOD: diatom predictive model for quality assessment of Portuguese running waters. Hydrobiologia. 2012;695:185-197. DOI: 10.1007/s10750-012-1110-4.

[13] Maddock I. The importance of physical habitat assessment for evaluating river health. Fresh Biol. 1999;41:373-391. DOI: 10.1046/j.1365-2427.1999.00437.x.

[14] Mophin-Kani K, Murugesan AG. Assessment of river water quality using macroinvertebrate organisms as pollution indicators of Tamirabarani River Basin, Tamil Nadu, India. Int J Env Prot. 2014;4.1:1-14. http://www.ij-ep.org/Issue.aspx ?Volume=4\&Number=1\&Abstr=false. 
[15] Zeybek M, Kalyoncu H, Karakaş B, Özgül S. The use of BMWP and ASPT indices for evaluation of water quality according to macroinvertebrates in Değirmendere Stream (Isparta, Turkey). Turk J Zool. 2014;38:603-613. DOI: 10.3906/zoo-1310-9.

[16] Vandewalle M, De Bello F, Berg MP, Bolger T, Dolédec S, Dubs F, et al. Functional traits as indicators of biodiversity response to land use changes across ecosystems and organisms. Biodiv Conserv. 2010;19:9798. DOI: $10.1007 / \mathrm{s} 10531-010-9798-9$.

[17] Galas J, Dumnicka E, Galus-Barchan A. A comparison of various indices based on benthic macrofauna for the assessment of the ecological status of selected Carpathian streams. Oceanol Hydrobiol Stud. 2014;43.(2):123-130. DOI: 10.2478/s13545-014-0124-0.

[18] AQEM Consortium. Manual for the Application of the Aqem System. A Comprehensive Method to Assess European Streams Using Benthic Macroinvertebrates, Developed for the Purpose of the Water Framework Directive. Version 1.0, February 2002. www.aqem.de; 2002. www.life-inhabit.it/cnr-irsa-activities/it/ download/.../15-aqem.

[19] Semenchenko VP, Moroz MD. Comparative analysis of biotic indices in the monitoring system of running water in a biospheric reserve. Water Res. 2005;32(2):200-203. DOI: 10.1007/s11268-005-0025-0.

[20] Leunda PM, Oscoz J, Miranda R, Arino AH. Longitudinal and seasonal variation of the benthic macroinvertebrate community and biotic indices in an undisturbed Pyrenean river. Ecol Indic. 2009;9:52-63. DOI: 10.1016/j.ecolind.2008.01.009.

[21] Sanchez-Montoya MM, Vidal-Abarca MR, Suarez ML. Comparing the sensitivity of diverse macroinvertebrate metrics to a multiple stressor gradient in Mediterranean streams and its influence on the assessment of ecological status. Ecol Indic. 2010;10:896-904. DOI: 10.1016/j.ecolind.2010.01.008.

[22] Jüttner I, Chimonides PJ, Ormerod SJ. Developing a diatom monitoring network in an urban river-basin: initial assessment and site selection. Hydrobiologia. 2012;695:137-151. DOI: 10.1007/s10750-012-1123-z.

[23] Böhmer J, Rawer-Jost C, Zenker A. Multimetric assessment of data provided by water managers from Germany: assessment of several different types of stressors with macrozoobenthos communities. Hydrobiologia. 2004;516:215-228. DOI: 10.1007/978-94-007-0993-5_13.

[24] Lucke JD, Johnson RK. Detection of ecological change in stream macroinvertebrate assemblages using single metric, multimetric or multivariate approach. Ecol Indic. 2009;9:659-664. DOI: 10.1016/j.ecolind.2008.08.005.

[25] Aazami J, Sari AE, Abdoli A, Sohrabi H, Van den Brink PJ. Assessment of ecological quality of the Tajan River in Iran using a multimetric macroinvertebrate index and species traits. Environ Manage. 2015;56:260-269. DOI: 10.1007/s00267-015-0489.

[26] Deng X, Xu Y, Han L, Yu Z, Yang M, Pan G. Assessment of river health based on an improved entropybased fuzzy matter-element model in the Taihu Plain, China. Ecolog Indicators. 2015;57:85-95. DOI: 10.1016/j.ecolind.2015.04.020.

[27] Stoddard JL, Larsen DP, Hawkins CP, Johnson RK, Norris RH. Setting expectations for the ecological condition of streams: the concept for reference condition. Ecol Appl. 2006;16:1267-1276. DOI: 10.1890/1051-0761(2006)016[1267:SEFTEC]2.0.CO;2.

[28] Applegate JM, Baumann PC, Emery EB, Wooten MS. First step in developing multimetric macroinvertebrates index for the Ohio River. River Res Applic. 2007;23:683-697. DOI: 10.1002/rra.1011.

[30] Timm H, Mardi K, Möls T. Macroinvertebrates in Estonian streams: the effects of habitat, season, and sampling effort on some common metrics of biological quality. Eston J Ecol. 2008;57:37-57. DOI: 10.3176/eco.2008.1.03.

[31] Gabriels W, Lock K, De Pauw N, Goethals PLM. Multimetric Macroinvertebrate Index Flanders (MMIF) for biological assessment of rivers and lakes in Flanders (Belgium). Limnologica. 2010;40:199-207. DOI: 10.1016/j.limno.2009.10.001.

[32] Bennett C, Owen R, Birk S, Buffagni A, Erba S, Mengin N, et al. Hydrobiologia, 2011;667:31-48. DOI: 10.1007/s10750-011-0635-2.

[33] Resh VH, Rosenberg DM, Reynoldson TB. Selection of benthic macroinvertebrate metrics for monitoring water quality of the Frazer River, British Colombia: implications for both multimetric approaches and multivariate models. In: Wright JF, Sutcliffe DW, Furse MT, editors. Assessing the Biological Quality of Freshwaters: RIVPACS and Other Techniques. Freshwater Biological Association, Ambleside, UK; 2000.

[34] Bunn SE, Davies PM. Biological processes in running waters and their implications for the assessment of ecological integrity. Hydrobiologia, 2000;422:61-70. DOI: 10.1023/A:1017075528625.

[35] Malmqvist B. Threats to the running water ecosystems of the world. Env Conserv. 2002;29:134-153. http://scholarworks.umt.edu/biosci_pubs/166.

[36] Gregory KJ. The human role in changing river channels. Geomorphology. 2006;79:172-191. DOI: 10.1016/j.geomorph.2006.06.018. 
[37] James LA, Marcus WA. The human role in changing fluvial systems: Retrospect, inventory and prospect. Geomorphology. 2006;79:152-171. DOI: 10.1016/j.geomorph.2006.06.017.

[38] Obolewski K, Gotkiewicz W, Strzelczak A, Osadowski Z, Astel AM. Influence of anthropogenic transformations of river bed on plant and macrozoobenthos communities. Environ Monit Assess. 2011;173(1-4):747-63. DOI: 10.1007/s10661-010-1420-9.

[39] Touron-Poncet H, Bernadet C, Compin A, Bargier N, Céréghino R. Implementing the Water Framework Directive in overseas Europe: a multimetric macroinvertebrate index for river bioassessment in Caribbean Islands. Limnologica. 2014;47:34-43. DOI: 10.1016/j.limno.2014.04.002.

[40] Kolanek A, Korol R, Strońska M, Szyjkowska U. Assessment of water pollution by nitrates in the Middle Odra Basin. J Water Land Dev. 2007;11:91-102. DOI: 10.2478/v10025-008-0008-z.

[41] Moog O. Water quality - Guidance on pro-rata multi habitat sampling of benthic invertebrates from wadeable rivers in the HKH Region. 2005. www.assess-hkh.at/...MHS_Manual_HKH_Nov05.p..PDF.

[42] Błachuta J, Szoszkiewicz K, Gebler D, Schneider SC. How do environmental parameters relate to macroinvertebrate metrics? - prospects for river water quality assessment. Pol J Ecol. 2014;62:111-122. DOI: $10.3161 / 104$.

[43] Solak NC, Àcs E. Water quality monitoring in European and Turkish rivers using diatoms. Turkish J Fish Aquat Sci. 2011;11:29-337. DOI: 10.4194/trjfas.2011.0218.

[44] Edington JM, Hildrew AG. A revised key to the case less caddis larvae of the British Isles with notes on their ecology. Scientific Publications. Freshwater Biological Associations. Cumbria; 2000.

[45] Birk S, Hering D. Water view web-database: a comprehensive review of European assessment methods for rivers. FBA News 20.4; 2002.

[46] Birk S, Hering D. Direct comparison of assessment methods using benthic macroinvertebrates: a contribution to the EU Water Framework Directive intercalibration exercise. Hydrobiologia. 2006;566:401-415. DOI: 10.1007/s10750-006-0081-8.

[47] Šporka F, Pastuchová Z, Hamerlík L, Dobiašová M, Beracko P. Assessment of running waters (Slovakia) using benthic macroinvertebrates - derivation of ecological quality classes with respect to altitudinal gradients. Section Zoology. Biologia. 2009;64:1196-1205. DOI: 10.2478/s11756-009-0201-9.

[48] Buffagni A, Crosa GA, Harper DM, Kemp JL. Using macroinvertebrate species assemblages to identify river channel habitat units: an application of the functional habitats concept to a large, unpolluted Italian river (River Ticino, northern Italy). Hydrobiologia. 2000;435:213-225. DOI: 10.1023/A:1004124717508.

[49] Böhmer J, Rawer-Jost C, Zenker A, Meier C, Feld CK, Biss R, et al. Assessing streams in Germany with benthic invertebrates: Development of a multimetric invertebrate based assessment system. Limnologica. 2004;34:416- 432. DOI: 10.1016/S0075-9511(04)80010-0.

[50] Korycińska M, Królak E. The use of various biotic indices for evaluation of water quality in the lowland rivers of Poland (Exemplified by the Liwiec River). Pol J Environ Stud. 2006;15:419-428.

[51] Višinskienè G, Bernotienè R. The use of benthic macroinvertebrate families for river quality assessment in Lithuania. Cent Eur J Biol. 2012;7:741-758. DOI: 10.2478/s11535-012-0052-1.

[52] Duran M. Monitoring water quality using benthic macroinvertebrates and physicochemical parameters of Behzat Stream in Turkey. Polish J Environ Stud. 2006;15(5):709-717. http://www.pjoes.com/abstracts/2006/Vol15/No05/05.html.

[53] Czerniawska-Kusza I. Comparing modified biological monitoring working party score system and several biological indices based on macroinvertebrates for water quality assessment. Limnologica. 2005;35:169-176. DOI: 10.1016/j.limno.2005.05.003.

[54] Raczyńska M, Grzeszczyk-Kowalska A, Chojnacki J, Raczyński M. Impact of taxonomic structure and benthic fauna biomass on the biological classification of river waters. Ecol Chem Eng A. 2012;19(4-5):421-431. DOI: 10.2428/ecea.2012.19(04)044.

[55] Nguyen HH, Everaert G, Gabriels W, Hoang TH, Goethals PLM. A multimetric macroinvertebrate index for assessing the water quality of the Cau river basin in Vietnam. Limnologica. 2014;45:16-23. DOI: 10.1016/jlimno.2013.10.001.

[56] Wyżga B, Oglęcki P, Hajdukiewicz H, Zawiejska J, Radecki-Pawlik A, Skalski T, et al. Interpretation of the invertebrate-based BMWP-PL index in a gravel-bed river: insight from the Polish Carpathians. Hydrobiologia. 2013;712(1):71-88. DOI: 10.1007/s10750-012-1280-0.

[57] Hering D, Johnson RK, Kramm S, Schmutz S, Szoszkiewicz K, Verdonschot PFM. Assessment of European streams with diatoms, macrophytes, macroinvertebrates and fish: a comparative metric-based analysis of organism response to stress. Freshwater Biol. 2006;5:1757-1785. DOI: 10.1111/j.1365-2427.2006.01610.x.

[58] Mutonkole SP. Benthic macroinvertebrates as indicators of water quality: a case-study of urban Funa Stream (in Kinshasa, Democratic Republic of Congo). Open J Water Pollut Treatment. 2015;2(1):8-24. DOI: 10.15764/WPT.2015.01002. 
[59] Guimarães RM., Facure KG, Pavanin LA, Jacobucci GB. Water quality characterization of urban streams using benthic macroinvertebrate community metrics. Acta Limnol Bras. 2009;21:217-226.

[60] Buffagni A, Erba S, Cazzola M, Kemp JL. The AQUEM multimetric system for the southern Italian Apennines: assessing the impact of water quality and habitat degradation on pool macroinvertebrates in Mediterranean rivers. Hydrobiologia. 2004;516:313-329.

[61] Hering D, Moog O, Sandin L, Verdonschot PFM. Overview and application of the AQUEM assessment system. Hydrobiologia. 2004:516:1-20. DOI: 10.1023/B:HYDR.0000025273.15958.6a.

[62] Pinto P, Rosado J, Morais M, Antunes I. Assessment methodology for Southern siliceous basins in Portugal. Hydrobiologia. 2004;516:191-214. DOI: 10.1023/B:HYDR.0000025266.86493.a2.

[63] Menetrey N, Oertli B, Lachavanne JB. The CIEPT: a macroinvertebrates based multimetric index for assessing the ecological quality of Swiss lowland pond. Ecol Indic. 2011;1:590-600. DOI: 10.1016/j.ecolind.2010.08.005.

[64] Camargo JA. The importance of biological monitoring for the ecological risk assessment of freshwater pollution: A case study. Environ Int. 1994;20:229-238. DOI: 10.1016/0160-4120(94)90140-6.

[65] Wetzel RG. Limnology. 3rd ed., New York: Academic Press; 2001.

[66] Camargo JA, Alonso A, De la Puente M. Multimetric assessment of nutrient enrichment in Impounded rivers based on benthic macroinvertebrates. Environ Monit Assess. 2004;96:233-249. DOI: 10.1023/B:EMAS.0000031730.78630.75.

[67] Lewin I, Jusik S, Szoszkiewicz K, Czerniawska-Kusza I, Ławniczak AE. Application of the new multimetric MMI PL index for biological water quality assessment in reference and human-impacted streams (Poland, the Slovak Republic). Limnologica, 2014;49:42-51. DOI: 10.1016/j.limno.2014.09.001.

[68] Sandin L, Johnson RK. The statistical power of selected indicator metrics using macroinvertebrates for assessing acidification and eutrophication of running waters. Hydrobiologia. 2000;422/423:233-243. DOI: 10.1023/A:1017082619481. 